\title{
AUDIT: LEGAL ASPECTS IN A PANDEMIC
}

AUDITORÍA: ASPECTOS LEGALES EN UNA PANDEMIA

\author{
Vitalii Olyukha* \\ Vladimira Dobrovolska** \\ Valentyna Chaikovska*** \\ Vadim Popeliuk \\ Juliia Dyshkantiuk $k^{* * * * *}$
}

\begin{abstract}
This article is devoted to changes in the economic and legal conditions of audit activity in the context of a pandemic and its consequences. It will be useful both to top managers of companies and to audit companies and their specialists. The object of the research is public relations in the field of auditing. The interests of the three main parties are distinguished separately: states, business and auditing companies. The work has the following structure: world experience in auditing during a pandemic;
\end{abstract}

\footnotetext{
* Doctor of Legal Science, Associate Professor, Leading Researcher of Department of Economic and Legal Support of Economic Security of the State, State Institution "The Institute of Economic and Legal Research named V. K. Mamutova" National Academy of Sciences of Ukraine (Kyiv, Ukraine). https://orcid.org/0000-0002-3339-1154. advokatvo@ukr.net

** Ph.D., Associate Professor of the Department of Commercial Law and Process, "National University Odesa Law Academy" (Odesa, Ukraine). https://orcid.org/0000-0002-93043792.vv_dobro@ukr.net

**** Ph.D., Associate Professor of the Department of Administrative and Commercial Law, Odesa I.I. Mechnikov National University (Odesa, Ukraine). https://orcid.org/0000-00032785-1369. vvchaykovskaya@ukr.net

**** Ph.D., Associate Professor of the Department of Commercial Law and Process, "National University Odesa Law Academy" (Odesa, Ukraine). https://orcid.org/0000-00027415-3996/advokat.vp@gmail.com

***** Ph.D., Associate Professor of the Department of Commercial Law and Process, "National University Odesa Law Academy" (Odesa, Ukraine). https://orcid.org/0000-00020928-6004. dyshkantiuk@gmail.com
} 
national legal framework for auditing: problems and solutions; the current state of the audit services market: problems and solutions; recommendations to the participants of the audit market. The research methodology is based on general and special scientific methods, in particular: historical-legal, formal-legal, comparative analysis, and modeling. The study concludes that it is the audit system that still acts as a locomotive for the business environment, since an audit is at the forefront of the latest technological solutions (processing Big Data, leveling information asymmetry), is able to quickly work with financial and economic reporting data and propose appropriate measures. However, for this, the business should not be afraid to change in the wake of this new changing world, and audit companies should quickly adapt to new trends and needs.

Keywords: Audit, Audit Services, International Auditing Standards, Financial Reporting, Pandemic

Resumen: Este artículo está dedicado a los cambios en las condiciones económicas y legales de la actividad de auditoría en el contexto de una pandemia y sus consecuencias. Será de utilidad tanto a los altos directivos de las empresas como a las empresas de auditoría y sus especialistas. Esta investigación se centra en las relaciones públicas en el campo de la auditoría. Los intereses de las tres partes principales se distinguen por separado: estados, sociedades comerciales y auditoras. El análisis se hace bajo la siguiente estructura: primero se ve la experiencia mundial en auditoría durante una pandemia; luego se analiza el marco legal nacional para realizarla, sus problemas y soluciones; a continuación se ve el estado actual del mercado de servicios de auditoría; y se finaliza con recomendaciones a los participantes del mercado de auditoría. La metodología de investigación se basa en métodos científicos generales y especiales, en particular: histórico-legal, formal-legal, análisis comparativo y modelización. El estudio concluye que el sistema de auditoría aún influye en el entorno empresarial: si el sistema está a la vanguardia de las últimas soluciones tecnológicas (procesamiento de big-data, nivelación de asimetría de información), es capaz de trabajar rápidamente con los informes económicos y proponer las medidas adecuadas. Sin embargo, para ello, la empresa no debe tener miedo de cambiar radicalmente en este mundo cambiante, y las empresas de auditoría deben adaptarse rápidamente a las nuevas tendencias y necesidades.

Palabras clave: Auditoría, servicios de auditoría, normas internacionales de auditoría, informes financieros, pandemia 
Summary. I. Introduction. II. Methodology. III. Analysis of recent research. IV. Results and discussion. IV.1. World audit experience during the pandemic. IV.2. National legal framework of audit: problems and ways to solve them. IV.3. The current state of the audit services market: problems and their solutions. IV.4. Recommendations for audit market participants. V. Conclusions. References.

\section{INTRODUCTION}

Numerous international declarations, conventions, and treaties regularly emphasize that human rights and freedoms and their continuous protection are the basis on which any civilized and developed modern country stands. But what is the basis for the satisfaction and realization of human rights and freedoms? Such a basis is the economy. But modern economic and legal economic conditions are characterized by a high level of turbulence, which is acted by numerous environmental factors that occur by chance, but their size and amplitude are subject to chaotic changes over time. Thus, the beginning of 2020 was marked for Ukraine and the world by the emergence of a global unmanageable factor that greatly affected the company's ability to continue operations, causing an economic recession that affected people's lives and the economy-the Covid-19 pandemic. Thus, disruptions in production, loss of business and jobs, and, as a consequence, the inability of the economy to meet basic human rights to work and a minimum standard of living have been the main consequences of the pandemic in terms of economic activity. Therefore, to ensure human rights and freedoms, it is first necessary to take care of the economic potential of our society.

With the growing influence of the new factor of structural transformations, there is a logical need to adapt innovative and potential technologies and tools together with the creation of appropriate institutional conditions to ensure business continuity, forming its economic security, which, in turn, which, in turn, is a shield for the balanced development of the economy in general and the welfare of the population in particular. In this aspect, the protection of the economy should be sectoral in the following areas: industry, agriculture, energy, transport and infrastructure, information and communication technologies, services.

We believe that the audit system is currently the locomotive for the business environment because the audit is a reliable tool for processing Big Data of the company, technology to level information asymmetry, confirmation of financial statements, which is necessary for both the company and its stakeholders, including shareholders, suppliers, creditors, investors, fiscal authorities, insurance companies and society as a whole. 


\section{Methodology}

The theoretical and methodological basis of the study is a set of general scientific methods of cognition of processes and phenomena, basic in the context of the study of the audit. The publication used: (i) epistemological method - to specify the content of categories and concepts that are the main emphasis in determining the essence of the audit; (ii) bibliographic and bibliometric analysis - to study trends and dynamics of audit development; (iii) modeling and formalization - to determine the information needs of management staff during the organization of the audit in a pandemic; (iv) observation and comparison-to reveal the organizational and technological features of the activities of audit entities in a pandemic; (v) analogies and abstraction-to develop methodological aspects of audit; (vi) system-structural analysis to specify the parameters of the audit as an element of the management system of the enterprise; (vii) methods of analysis and symbolic logic for the formation of proposals for the development of audit based on information and communication technologies in a pandemic; and (viii) a method of generalization to increase the informativeness of the audit to ensure the management system.

All of the above methods have made it possible to thoroughly, fully, and objectively investigate the problems of economic and legal regulation of auditing in the context of the Covid-19 pandemic.

The information base of this publication is the laws and regulations of Ukraine on the regulation of the organization of the audit; reference and methodological documents; scientific works of the scholar on the theory and practice, organization, audit methodology; periodicals, statistics; information from the Internet; the results of our own experience in audit research.

\section{ANALYSIS OF RECENT RESEARCH}

Given that the development of the audit market began in Ukraine only after gaining independence and the deployment of relevant market reforms, it is natural that national theory and practice quickly borrowed experience from foreign colleagues. In particular, the doctrinal basis and source of valuable practical experience were the works of the following foreign scholars: Loeb, and Shamoo (1989), Matthews (2006), Ladda (2014), Clarke, Walsh, Flanagan (2015).

Modern local specifics and tendencies of audit development in Ukraine were studied by such scientists and specialists as: Dolbneva (2018), 
Zhukova, Ganus, and Plikus (2019), Kashperska (2018), Mulyk (2020), Popov (2020), Shevchenko, and Lipnytska (2019), Shulga (2019), Prokhorova, and Yukhimenko (2019).

Hence, in her work, Kashperskaya (2018) analyzes the current state and prospects for the development of auditing in Ukraine through the prism of problematic issues of the current audit system, the solution of which she sees in the application of international financial reporting standards. Thus, the scholar notes the modernity and prospects of implementing International Financial Reporting Standards (hereinafter "IFRS") in increasing the investment attractiveness of Ukrainian enterprises, as the transition to international financial reporting standards in the current business environment will lead to an increase in the number of audits of companies that report under IFRS, which is important not only for foreign but also for domestic investors. In addition, the author emphasizes the need to introduce the profession of the auditor in business practice, which will contribute to the formation of high confidence and confidence in the high competence of domestic auditors.

The team of authors led by Zhukova (2019), considering the current problems of audit services in Ukraine, emphasizes, first of all, the monopolization of the market by four companies, which account for $0.4 \%$ of the total number of audit entities in Ukraine in 2018. Researchers also highlight the shortcomings and unresolved issues of audit firms, including lack of a unified audit program, pricing of audit services, insufficient methodological development of audit control, the cost of auditor certification, and lack of guidelines for computerization of audit (Zhukova, Ganus \& Plikus, 2019).

Mulyk (2020) notes the imperfection of the regulation of the audit market in Ukraine, which has led to problems in confirming the quality and reliability of financial statements, which in turn increases the risk of bankruptcy of enterprises and banks and reduces confidence in them by potential investors, who were attracting investment in the national economy as a whole. Besides, the author notes the tendency to reduce the number of audit entities, while increasing the cost of their services.

What is more, Shevchenko and Lipnytska (2019) considers the essence and development of audit in the European integration environment by retrospective analysis of the formation of audit in the world. The author proposes to solve several audit problems in Ukraine by studying the foreign experience of foreign audit firms operating in the country.

Further, Shulga (2019) emphasizes on the need to take into account the impact of legislative changes in the field of auditing on the definition of audit services that can be provided. Given the legislative innovations, the 
author proposes a classification of audit services with an in-depth understanding of their substantive characteristics, which will improve the organizational and methodological support of various types of audit services, audit risk assessment and audit market development in general.

Scholars Prokhorov and Yukhimenko (2019) analyze the current state and problems of reform and development of auditing in Ukraine. The authors propose to improve the audit system through information and communication technologies.

Moreover, Dolbneva (2018) sees the development of audit in Ukraine as a comprehensive system of measures taking into account the requirements of European Union legislation and international standards, as it will control the level of professional competence of auditors and the quality of services provided, ensure the real professional independence of the auditor and allow the development and implementation of sanctions and penalties for auditors for the inaccuracy of their provision of audit services and a report on their results.

Partner of Kreston GCG, Popov (2020) examines current audit trends - the 2020-2023 strategy of the International Auditing and Auditing Standards Board (IAASB), aspects of global tax reform, innovative digitalization, and development of technologies that will allow instant access to analytical programs, as well as changes in the audit of the reporting of European companies, taking into account Brexit.

Such scholars as Melnyk and Nakonechna (2018), Petrytska (2019), Sonin (2020) devoted their works to the theoretical and practical aspects of the organization of internal audit. Researchers Nakonechna and Melnyk (2018) see internal audit as a factor in increasing competitiveness by achieving strategic and operational goals, to effectively manage the enterprise.

Moreover, Petrytska (2019) states the expediency of creating an internal audit body at the enterprise as a solution to the problem of its organization. The author emphasizes that internal audit is the only opportunity for the owner to control the changes that occur, and the proper organization of internal audit directly affects the effectiveness of control and analysis of financial and economic activities of the enterprise.

Besides, Sonin (2020), director of the Institute of Internal Auditors, believes that the pandemic is a time to unleash the potential of internal audit, as the business has changed and will operate under new laws, so the expert calls for an initiative to help the company's management see and assess risks.

Without diminishing the authors' scientific work, more detailed and in-depth research requires theoretical and practical provisions to substantiate the content of the audit in the context of the Covid-19 pandemic, which currently dictates the business conditions. 


\section{RESULTS AND DISCUSSION}

\section{IV.1. World audit experience during the pandemic}

The Covid-19 pandemic has posed some challenges that must be accepted and overcome by the international community, including the country's Supreme Audit Institutions (SAIs). Thus, the analysis of the SAIs activities on official websites and official pages on social networks shows that the vast majority, which amounted to more than $70 \%$, at the peak of the pandemic, switched to remote work mode or partial remote work mode with the involvement of the minimum required number of employees in the offices following the changes determined by the work schedule.

Thus, the following vectors were identified, which streamlined the activities of SAIs during the Covid-19 pandemic:

-the transition to remote operation, including setting up an online format for resolving issues;

-inspections and formation of internal documents of SAIs in the direction of Covid-19;

- carrying out emergency measures; increasing the openness of SAIs;

- raising public awareness of Covid-19;

-active publishing activities on the topic of Covid-19; direct involvement of SAIs in the fight against Covid-19, and;

- advanced training of SAIs employees.

Fig. 1. Distribution of SAIs by mode of operation.

Data provided by the Accounts Chamber of Russian Federation (2020).

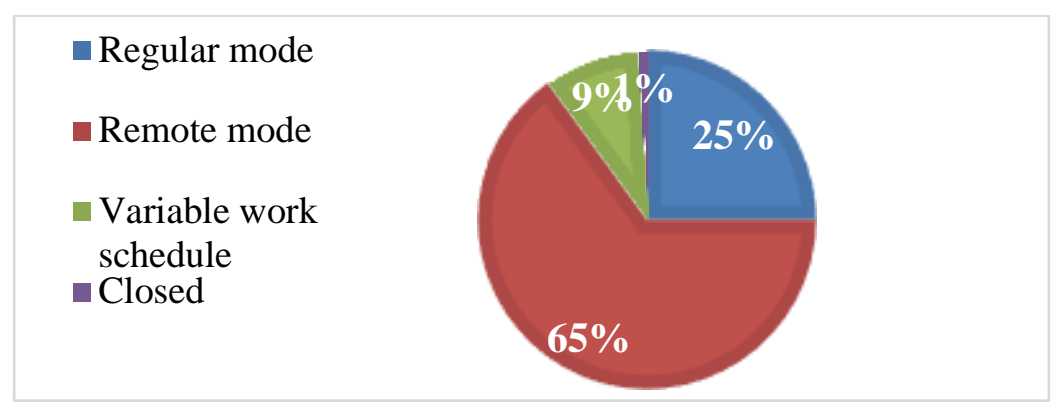

Figure 1 shows the mode of operation of SAIs in 76 countries. Thus, SAIs from Argentina, Brazil, Denmark, China, Mexico, Ecuador, and Estonia are active online. In Denmark, in particular, SAIs carry out new remote audits: the verification of the accounting policy of the Danish postal service (PostNord), as well as the analysis of appeals to the court on inheritance cases. 
In an article in El Financiero, Mexico's SAIs chairman Colmenares Paramo (2020) described how, in the context of the SAIs pandemic, digitalization is being developed: an electronic taxpayer's office (el Buzón Fiscalizador) has been set up to conduct a remote audit; planning, audit, and control processes are integrated into an integrated control system developed by SAIs.

Besides, in Austria, SAIs conducted a health inspection and found a lack of action to address hospital bed shortages and the purchase of medicines.

Furthermore, Brazil's SAIs plan to monitor the actions of the authorities under the Covid-19 Anti-Proliferation Monitoring Action Plan. Monitoring will be carried out through virtual meetings and the use of IT tools. In particular, it is planned: (i) to monitor the measures of the Central Bank of Brazil to mitigate the economic and financial consequences of the virus; (ii) the effectiveness of federal state-owned banks (Caixa, BB, BASA, and BNB) in risk management; (iii) measures for digital transformation; (iv) emergency actions of the Ministry of Agriculture, Livestock and Supply; measures taken by the Ministry of Science, Technology, Innovation, and Communications, and their subdivisions; (vi) actions related to basic education in a crisis; (vii) measures are taken by the Ministry of Health (including relevant bodies and structures); and, (viii) measures in the tax and social spheres, in the field of health care, fuel policy, etc.

In the UK, SAIs analyze the government's preparedness for a pandemic, examine the costs of health measures, and protect businesses and individuals from their economic consequences.

Morevoer, Venezuela's regional auditing bodies are conducting checks to inflate prices for basic necessities and medical supplies.

Also, the SAIs of Vietnam will strengthen control over the implementation of measures to support citizens in difficulty through Covid-19.

In Germany, the SAIs published on its official website an analytical report on the pandemic measures taken, entitled "Measures of the Federal Budget Policy to Combat the Impact of the Covid-19 Pandemic (Key Data of the Supplementary Budget 2020)". The analytical part of the report is a brief summary of the economic measures taken, information on the additional budget and budget increase, public debt, economic stabilization funds, manuals to reduce working hours, evaluation of measures taken from a financial point of view. The report also provides detailed data on changes in the federal budget (including the supplementary budget for 2020) and two graphs: visualization of the supplementary budget and visual information on how the package of measures to combat the crisis caused by the pandemic affects the federal financial sector. 
China's SAIs audit funds and donations as part of pandemic prevention and control measures. The audit covers trust funds, donated funds, and goods, loans to key manufacturers of anti-epidemic products. In addition, to organize work remotely, the Golden Audit Project system was developed, which is designed to ensure prompt communication between employees, allows video conferencing, as well as simplifies data handling, and minimizes the need for on-site inspections.

In March, the SAIs of Colombia set up a special Monitoring Center, which will conduct real-time preventive monitoring of the spending of funds allocated to the fight against Covid-19 and measures taken by the government. SAIs require uploading information about contracts entered into as part of the implementation of measures to combat Covid-19. Control will be exercised based on unrestricted access to the necessary information, in the form of face-to-face or remote, and carried out at all stages of decisionmaking by public authorities, without the right to interfere in decisionmaking. The coordination and management of the process are entrusted to the Deputy Comptroller General and the authorized auditor in the field of "health care". All employees are instructed to assist in the implementation of this task without compromising the core business. Priority will be given to the use of IT technologies (KPMG, 2020).

Given the proximity of Colombia and Ukraine on issues such as the Romano-Germanic legal system, a similar standard of living, and financial capabilities of the country, we recommend that domestic officials and specialized professionals pay special attention to the experience of Colombia.

For several months, the New Zealand SAIs will monitor government spending on Covid-19, which will result in a report, which will be presented to the public and parliament.

Using social networks (Twitter, Facebook) and official sites, SAIs of Austria, Argentina, Estonia, Canada, Colombia, South Africa, Russia, USA, Turkey, France, the Czech Republic raise public awareness of Covid-19, thus preventing the spread of fraud in this area (Accounts Chamber of Russian Federation, 2020). Official accounts from government health authorities and social assistance networks in their promotion turned out to be a fairly cheap and simple way to reach a large part of the population and helped to stop the potentially dangerous movements of "crown-displaced".

DQS Group International, a certification and evaluation partner for quality-oriented companies for supermarket chains, shopping malls, and hardware stores; public transport enterprises, railways and air carriers, tour operators; cultural sites and museums; restaurants and hairdressers; administrative buildings and industrial premises currently offers (in the 
conditions of pandemics and epidemics) an audit of due diligence and certification for disinfection of public premises (DQS CFS, 2020).

Hence, in the field of audit, the pandemic has given a new impetus to both the diversification of its species and the vectors of its development. Thus, the conditions of the Covid-19 pandemic have revealed the additional potential of the SAIs of different countries, with different economic systems and national mentality, and to use them effectively and, most importantly, quickly. Thus, the organization of work in the remote mode comes to the fore, which will significantly reduce the costs of both enterprises and employees themselves. In turn, remote work requires the introduction of a qualitatively new level of information and communication technologies, so it is expected that this industry will become more innovative. However, first of all, business leaders need a quality and effective system of control and verification of both the operational and financial, and investment aspects of the business entity, which will allow implementation even during the pandemic developed audit system.

We believe that it is advisable for domestic auditors to study the experience of foreign SAIs and implement ready-made audit solutions in their activities to optimize costs.

\section{IV.2. National legal framework of audit: problems and ways to solve them}

Auditing is one of the main elements of the market infrastructure of countries with developed market economies. According to Art. 362 of the Commercial Code (2003), auditing is an independent professional activity of auditors and auditing entities registered in the Register of auditors and auditing entities for the provision of auditing services.

A qualitatively new stage in the development of auditing in Ukraine was the adoption of the Law of Ukraine "On the audit of financial statements and auditing activities" of December 21, 2017, $\mathrm{n}^{\circ}$ 2258-VIII (hereinafter "Law 2258"), which aims to bring national legislation in the field of auditing in line with EU rules and legislation, as it is based on the provisions of Directive 2006/43/EU (2006) and Regulation 537/2014 (2014), which regulated audit reform in the European Union in 2016. Law 2258, harmonized with EU legislation, is expected to promote the development of auditing in Ukraine, as well as improve the investment attractiveness of the national economy.

Following Law 2258, an audit of financial statements is an audit service to verify the accounting data and indicators of financial statements and/or consolidated financial statements of a legal entity or a representative office of a foreign entity or another entity that submits the financial 
statements and consolidated financial statements of the group, to express the auditor's independent opinion on its compliance in all material respects with the requirements of national accounting regulations (standards), international financial reporting standards, or other requirements. At the same time, the audit service is an audit, review of financial statements, consolidated financial statements, other assurance engagements, and other professional services provided under international auditing standards.

A significant innovation of Law 2258 is the clarification and significant expansion of the list of services that can be provided in the framework of auditing: (i) audit of financial statements; and (ii) 2. non-audit services (by type).

At the same time, the organizational and methodological provisions of the audit and the list of audit services that may be provided by audit entities (hereinafter "SAD") are given in the International Standards on Auditing (hereinafter "ISA"), which are also the regulator of auditing in Ukraine, The approved classification of audit services provided in the framework of auditing activities is as follows: (i) audit and review of historical financial information; (ii) assurance tasks other than auditing and reviewing historical financial information; and (iii) related services (services that include agreed procedures and information compilation).

In this context, we note the problem of lack of coherence at the legislative level between the provisions of the Law on the list of non-audit services and the list of related services in ISAs, because, according to the Law, in terms of providing non-audit services at the legislative level statutory audit of financial statements and non-audit services. The ISA does not provide for these restrictions. Obviously, such confusion could cause problems in the future. Why the legislator did not implement international norms but tried to do something of his own-it is not clear, there are no explanatory comments on this matter. We believe that the revised classification of non-audit services, taking into account the related services of ISAs, will allow the auditor to comply with professional liability, reduce the possibility of penalties for professional misconduct against the auditor and the auditor, and expanded powers.

A positive innovation of Law 2258 is the expansion of the range of legal entities that are required to disclose financial statements together with the audit report - these are companies of public interest. Referring to the Law of Ukraine "On Accounting and Financial Reporting in Ukraine" ${ }^{\circ}$ 996 (1999), these are enterprises-issuers of securities, the securities of which are admitted to trading on stock exchanges; banks, insurers, private pension funds, other financial institutions (except for other financial institutions and non-state pension funds belonging to micro and small enterprises); large 
enterprises; public joint-stock companies; medium enterprises. In the same aspect, the decision of the ACU Council of February 21, 2019, approved the Position of the Audit Chamber of Ukraine (ACU - a body of professional self-government of auditors, whose powers are determined by Law 2258 and the Statute) to determine cases of statutory audit and audit entities, carrying out mandatory audit: by subjects of natural monopolies on the national market; subjects of natural monopolies on the national market; financial institutions belonging to micro and small enterprises. At the same time, the issue of the mandatory audit also arises when auditing the financial statements of enterprises of the state and municipal sectors of the economy. We consider this point of Law 2258 to be a positive innovation, as the financial statements confirmed by the audit form the trust of foreign partners and stimulate the development of investments in Ukraine. However, in the same aspect, we found another legislative inconsistency, namely regarding the criteria for the division of enterprises by size in the Commercial Code. Undoubtedly, this is a problem because it threatens companies with penalties. Therefore, a necessary step is to bring the criteria for the division of enterprises to a single one in the Commercial Code and in Law 996. (Shulga, 2019).

In the context of considering the legal framework of the audit, we note another positive point, namely-defined by Law 2258 requirements that establish high organizational barriers to entry in the segment of statutory audit, namely: ensuring the independence and objectivity of auditors, introduction of internal control, risk assessment, protection of information processing systems, implementation of internal policies and procedures for performing tasks, staffing of the audit firm by certified specialists. In my opinion, this will significantly improve the quality of audit services and investor confidence but may affect the price of the service, although in a pandemic, increasing the cost of services is not a competitive advantage.

The moment of creation of a new regulatory body under Law 2258the Body of Public Oversight of Auditing Activities, which consists of the Audit Oversight Board and the Quality Assurance Inspectorate, should be singled out. The process of forming a Supervisory Board is questionable, namely the fact that it should include authorities and non-practitioners, although having experience in auditing, accounting, law for at least 10 years, and an impeccable reputation. However, government officials do not have to be non-practitioners. That is, there may be a threat of conflict of interest, as well as the combination of interests of government and business, which contradicts the country's chosen course of separation of government and business. Therefore, in this context, I propose in the Law when electing candidates to the Supervisory Board: (i) clarify the fact of the selection of 
candidates from non-practitioners; and (ii) clarify the persons delegated from the authorities and the procedure for identifying the presence or absence of their connection with the practical audit activities.

It is the clash of interests when working in the state service with an already familiar company or people that is the Achilles heel of the state statutory audit, as reported by colleagues from other countries (Moore, Tetlock, Tanlu \& Bazerman, 2006).

The solution to this problem is not easy, since it is difficult to form a specialist without first working in a business, however, narrow areas of responsibility and geographic rotation make it possible to smooth this problem (Ishaque, 2019).

Considering the sectoral specifics of audit, it is worth referring to the Law of Ukraine "On Environmental Audit" n 1862-IV (2003), which regulates the basic legal and organizational principles of environmental audit. The main issues of the Law are aimed at improving the environmental feasibility and efficiency of economic entities, which in the fight against the Covid-19 pandemic becomes especially relevant. I believe that the problem of mandatory environmental audit in the post-pandemic period may become an urgent issue, since the current government policy is aimed at complying with EU norms, especially in terms of the environment, and Law 2258 was no exception. The attention of the state, which is now riveted to the pandemic, after it, will inevitably return to environmental issues and heavy fines in case of violation of toughened environmental legislation. So companies should be prepared in advance by testing the development of a contingency budget for this case today. Additionally, in this context, a major innovation of Law 2258 is the mandatory submission of the Management Report, a document containing financial and non-financial information that characterizes the state and prospects of the enterprise and reveals the main risks and uncertainties of its activities. Entrepreneurs have many questions about the information that should be covered in this Report, however, under the guidelines provided by the Ministry of Finance, it should include environmental aspects, which we believe may lead to mandatory environmental audits in the future.

We should also highlight the medical audit, which has become a profitable venture in connection with the pandemic. On the one hand, the government has shifted responsibility for compliance with safety rules to employers, who are now intimidated by large fines for non-compliance. On the other hand, employers themselves are interested in the continuous functioning of their companies and the health of employees, therefore, in some places, they take additional security measures to state ones. Thus, specialists who check compliance with new safety and hygiene standards, 
set up disinfection equipment, help employees adapt to new requirementshave become very much in demand and are well paid. Contrary to the opinions of skeptics, a similar situation can be seen in different industries and companies (Stangoe \& Milan, 2020).

The above-mentioned DQS Group International, which has become one of the pioneers in this business, confirms the presence of demand with an ever-growing list of services. Thus, those audit companies that do not yet provide medical audit services are recommended to pay attention to this industry, most likely, the medical audit will be relevant until the end of the pandemic.

Thus, the current state of audit legislation in Ukraine as a whole can be assessed as positive, as important steps have been taken in the organizational and methodological provisions of the audit through the implementation of Law 2258, however, the following problems need improvement: (i) clarify at the legislative level the classification of non-audit services, taking into account the related services of ISAs; (ii) lead to a single interpretation of the criteria for the division of enterprises by size in the Commercial Code; and (iii) during the election of candidates to the audit supervisory Board to clarify the fact of election of candidates from nonpractitioners; clarify the persons delegated from the authorities and the procedure for identifying the presence or absence of their connection with the practical audit activities.

\section{IV.3. The current state of the audit services market: problems and their solutions}

According to the information provided by the Audit Chamber of Ukraine (ACU), in 2019, there were 2720 auditors. As of December 31, 2019, there were 900 auditing entities in the Register, including 861 audit firms and 39 natural persons-entrepreneurs. The largest number of SADs is concentrated in the Kyiv and Kyiv region, namely: 433 audit firms and 16 individual entrepreneurs, including the Big Four: PricewaterhouseCoopers, Ernst \& Young, KPMG, Deloitte Touche Tohmatsu Limited, and the TOP20 audit companies of Ukraine. Developed infrastructure and communications determine the location of enterprises. Large enterprises choose the capital as the location of their parent companies. This indicator indicates the geographical uneven functioning of the audit market, which in turn leads to an uneven distribution of orders, the volume of audit services provided, the cost of orders, and the income of audit entities.

The problem remains the negative dynamics of the number of SAD for the period 2015-2019: from 1071 in 2015 to 900 in 2019, while the indicator 
of the total volume of services provided by SAD for the period under review there is a steady upward trend, so in 2019 the total number of services provided in the amount of UAH 2,870,887. $1^{1}$ thousand, which is $432,787.00$ thousand UAH more than in 2018 . The volume of services provided by SAD in 2019 by region is presented in the next table.

Table 1. The volume of services provided by SAD in 2019 by region. Data provided by Audit Chamber of Ukraine (2019).

\begin{tabular}{|lcc}
\hline Region & $\begin{array}{c}\text { The number } \\
\text { of orders }\end{array}$ & $\begin{array}{c}\text { Financial volume of orders } \\
\text { (thousand hryvnia) }\end{array}$ \\
\hline Cherkasy Oblast & 523 & 10800,7 \\
Chernihiv Oblast & 229 & 2910,5 \\
Chernivtsi Oblast & 163 & 2286,6 \\
Donetsk Oblast & 3588 & 160507,6 \\
Ivano-Frankivsk Oblast & 83 & 4018,5 \\
Kharkov Oblast & 595 & 11904 \\
Kherson Oblast & 2826 & 75390,4 \\
Khmelnitsky Oblast & 300 & 6809,3 \\
Kyiv Oblast & 413 & 13841,4 \\
Kirovograd Oblast & 16582 & 2350082,9 \\
Luhansk Oblast & 133 & 5173,9 \\
L'viv Oblast & 48 & 1193 \\
\hline Mykolayv Oblast & 2166 & 72661,5 \\
Odesa Oblast & 418 & 6920,2 \\
\hline Poltava Oblast & 1283 & 49129,7 \\
\hline Rivne Oblast & 380 & 11282,5 \\
Sumy Oblast & 292 & 6020 \\
Ternopil Oblast & 323 & 5774,4 \\
Vinnitsa Oblast & 276 & 5766,1 \\
Volyn Oblast & 374 & 11230,3 \\
Zakarpattia Oblast & 226 & 3487,1 \\
Zaporizhzhia Oblast & 195 & 10484,4 \\
Zhytomyr Oblast & 1323 & 32231,1 \\
\hline Ukraine & 505 & 10981 \\
\hline
\end{tabular}

${ }^{1}$ The average exchange rate of the hryvnia to the US dollar for 2019 is $25.1 \mathrm{UAH}$, so we are talking about a figure of 115 million dollars. 
Considering the activities of the SAD in the current conditions of the Covid-19 pandemic, according to the State Statistics Service of Ukraine for the 1st quarter of 2020 there was an increase in services provided by enterprises in the field of accounting and auditing, tax consulting compared to the 4th quarter of 2019 by 780215, 9 thousand UAH. However, the active phase of the Covid-19 pandemic in Ukraine began on March 25, with the introduction of quarantine and restrictive measures by the Cabinet of Ministers of Ukraine aimed at counteracting its further spread in Ukraine on March 11, that is, it is in the second quarter of 2020 that the highest level of uncertainty of the situation and management decisions made in this regard by the management of enterprises.

According to the Covid-19 Global Study: Impact on Business and Counteraction, conducted by the Association of Chartered Certified Accountants (ACCA), the Covid-19 pandemic had a significant impact on auditing. While digital progress continues to affect audit and evidence collection methods, as well as the reporting process, for many audit firms the pandemic has caused a systemic shock and made it difficult to work with clients: $53 \%$ said they feel pressured to serve clients, $36 \%$ said that it is unable to meet the reporting deadlines that have been allowed by many countries where the reporting deadline has been extended. A quarter of respondents said they had difficulty gathering audit evidence, and $27 \%$ said they saw an increased audit risk associated with asset valuation, performance, or continuing operations. On this issue, ACCA Director Suffield said: "The issue of increasing pressure to complete audit work, obtain audit evidence, and very important judgments in areas such as continuing operations force auditors to re-evaluate how they perform normal audit activities. There are challenges ahead of us, but respondents also see opportunities" (Chamber of Auditors and Accountants of Ukraine, 2020).

We consider that such challenges cannot be overcome by the company on its own, and therefore in uncontrolled circumstances, they should be mitigated by measures taken by the state. Indeed, the solution to the problem of entrepreneurship awareness during the pandemic was the launch by the Ministry of Economic Development, Trade and Agriculture of Ukraine together with the Export Promotion Office of an online platform for informing entrepreneurs, which contains information on government support for business in the pandemic Covid-19; answers to current questions of entrepreneurs; electronic database for training and development.

Undoubtedly, a serious problem of the SAD's activities was the conduct of the remote audit, as there was a need to quickly develop additional procedures to ensure the appropriate level of quality, which in 
turn is an additional cost item that was not planned by management accounting (Popov, 2020).

Besides, consumers of SAD services are also forced to reduce their costs, often by refusing additional services, including auditing. That is why, to support the SAD and minimize the impact of negative factors on the stability of the audit market in Ukraine in the context of the Covid-19 pandemic, the ACU Council adopted a decision "On Amendments to the Decision of the Audit Chamber of Ukraine the amount of the contribution paid by the auditing entities in favor of the Audit Chamber of Ukraine". The decision provides for a reduction in the amount of the contribution paid by SAD to the ACU in the period from January 1, 2020, to December 31, 2020, from $0.8 \%$ to $0.2 \%$ of the amount of remuneration (excluding VAT) under the contract for the provision of audit services for the statutory audit of enterprises that are not of public interest, and the possibility of crediting overpaid amounts of contributions to future payments (Audit Chamber of Ukraine, 2020).

The ACU Letter on Non-Application of Penalties for Untimely Disclosure of Financial Statements for 2019 should be singled out due to numerous appeals by ACU members expressing concern about the possibility of timely preparation of financial statements for subsequent publication together with the audit report. Note that under the Art. 163-16 Code of Administrative Offenses (1984) established the following fines for violation of the order of disclosure of financial statements: 17000-34000 $\mathrm{UAH}$ - from one thousand to two thousand non-taxable minimum incomes of citizens for the first violation; 34000-51000 UAH-from two thousand to three thousand non-taxable minimum incomes of citizens for repeated violations during the year. Therefore, following the amendments to Section V "Final Provisions" of the Law of Ukraine "On Accounting and Financial Reporting in Ukraine" $\mathrm{n}^{\circ} 996$ (hereinafter - the Law 996), the terms of publication of financial statements, including consolidated, have been extended, together with the auditor's report for 2019. Thus, the financial statements and consolidated financial statements for 2019, together with the auditor's report, may be submitted and published within 90 calendar days from the day following the end of quarantine, but not later than December $31,2020$.

One might get the impression that these steps will reduce the tax base and state resources, but the situation is exactly the opposite. As we found out above, the entire volume of the audit market in Ukraine is about UAH 2.8 billion, which is less than $0.1 \%$ of the country's Gross domestic product (GDP) (MinFin, 2020). Thus, on a national scale, tax revenues from this 
sector are not significant, but the assistance that the audit provides to other enterprises is invaluable.

Accordingly, at a time when the pandemic is creating a lot of financial, operational, and personal difficulties, we believe that it is necessary to weaken government influence to support audit firms locally to maintain urban infrastructure by extending tax breaks, temporarily abolishing fines, extending the moratorium for inspections.

\section{IV.4. Recommendations for audit market participants}

The conditions of the Covid-19 pandemic have shown that companies can work virtually, saving time and money, and therefore look for opportunities to reduce the cost of services. We believe that to maintain the effectiveness of the SAD, it is necessary to introduce the use of the following tools for the implementation of audit services now and in the long run:

1. Outsourcing. The threat of the second wave of the pandemic is quite real, and therefore the use of remote services makes the structure of work adapted to current conditions. This will significantly reduce the cost of organizing and maintaining the workplace. Besides, the company may find representatives of its company abroad instead of sending a specialist and losing working days in quarantine. The main problem of outsourcing is the loss of corporate culture, as professionals from other countries will not identify with a particular company. The solution to this problem is in a new management format.

2. The innovative format of SAD management. In times of uncertainty and remote work, it is especially important to organize the work of the team in an atmosphere of trust and desire to share experiences, by creating a remote space for daily communication (group in a social network or messenger) to discuss current work issues, informing management supporting the company during a pandemic, stimulating initiative, conducting training. In addition, the digitalized work of professionals requires training and the creation of clear instructions from management.

3. Finding customers and building their trust. Self-promotion through the distribution of useful content in the information technology system: free webinars, YouTube videos, blogging, site content. Unfortunately, without this, even auditing companies find it difficult to have a competitive marketing strategy. In the provinces, there are still many companies that do not use audit services because they do not understand how it can help them or do not trust them. It also helps with recruiting new employees by increasing awareness. 
4. Development of comprehensive solutions for consumers of audit services in the areas of audit: audit to confirm financial statements; audit to verify the effectiveness of the business; audit to attract investment; audit for business acquisition; audit to detect fraud (financial investigation); preparation of corporate annual reports and management reports (Zhukova, Ganus \& Plikus, 2019).

5. Optimization of pricing: monitoring of competitors' prices; staffing of specialists to avoid the involvement of outside specialists, maximum automation of projects; introduction of a system of discounts for the pandemic period; dialogue with the client to explain the transparency of the price-quality relationship; setting a fee that is appropriate.

Of course, the whole business is currently in a difficult situation. An acute issue is a receipt by the heads of structural units of operational, relevant, unbiased information on the state of the enterprise's resources to make management decisions and plan management strategy. In this context, the solution to the following issues becomes relevant:

- The need to develop and implement an effective control system that would improve the quality and efficiency of the enterprise, savings, optimization, and improvement of business processes, as well as would allow timely detection and elimination of errors.

- Prevention of illegal, inefficient, and ineffective use of enterprise funds. Control and detection of fraud.

- Providing confidence in the accuracy of the information and its compliance with established quality criteria.

- Multi-vector analysis of enterprise performance indicators according to selected criteria.

- Informing management about the compliance of the implementation of strategic and tactical goals selected by management policy by their responsible executors.

- Providing independent conclusions and recommendations on minimizing or eliminating risks to achieve the strategic goals of the enterprise.

- Ensuring the evaluation (effectiveness, relevance) of the company's departments.

Constant crises of economic nature affect the formats and strategies of business of all entities of different scales of the economic process. Because of this, the issue of protecting the economic side of doing business is still relevant, especially in the current political and economic instability of Ukraine. In this context, the question of finding new and more effective forms of control of the internal environment of enterprises and forecasting 
and prevention of internal and external threats becomes more acute (Nakonechna \& Melnyk, 2018).

We believe that both in the current pandemic and in the future, given the turbulence of the environment, it is the audit is a control system that will respond quickly to fluctuations in the economic environment, taking into account social and political factors that reduce the impact of factors that are uncontrolled for the enterprise. Thus, the systematic conduct of the audit will allow managers: (i) to determine the legitimacy of the data management system, financial and management accounting and reporting following regulations and internal organizational regulations of the enterprise; (ii) to check the availability and correctness of relevant documentation at the enterprise; identify recognized costs that are not documented; (iii) to provide an assessment of the effectiveness of management decisions; and (iv) to prepare explanations and recommendations for the centers of responsibility.

\section{CONCLUSIONS}

1. The Covid-19 pandemic has modified the reality of the business environment and forced business leaders to actively seek not so many new ways to develop their activities, but, above all, resources to maintain the continuity of the business entity at the existing level. The complex audit procedure allows solving this question in actual stressful conditions of conducting the activity. It is able to unleash its potential as the best business partner, because, acting as an advisory function, it allows to provide an objective assessment of the response to the crisis, as well as to ensure the plan and implementation of anti-crisis measures taken by the company management.

2. The Law of Ukraine "On Auditing Financial Statements and Auditing Activities" was adopted to address the development of auditing in Ukraine and to improve the investment attractiveness of the national economy, but unfortunately, it revealed many inconsistencies, including the Commercial Code of Ukraine and ISA, which leads before imposing penalties on the SAD. It is necessary to clarify at the legislative level the classification of non-audit services, taking into account the related services of ISAs and the criteria for the division of enterprises by size in the Commercial Code of Ukraine.

Thus, during the election of candidates to the Audit Supervisory Board to resolve the problem of conflict of interest and the emergence of risks in the activities of the Public Oversight Body, we propose to clarify in the Law the fact of election of candidates from non-practitioners; clarify the persons 
delegated from the authorities and the procedure for identifying the presence or absence of their connection with the practical audit activities.

3. As part of the mandatory submission of the Management Report, which already contains a section on environmental aspects, the issue of mandatory environmental audit for a wide range of companies is already a reality. We advance companies to prepare in advance for this step by conducting an environmental audit.

4. An important issue for auditing entities was the streamlining of activities in a pandemic, which the highest audit bodies of different countries proposed to solve by switching to the remote mode of operation, including setting up an online format for resolving issues; inspections, and formation of internal documents of the SAIs in the direction of Covid-19; carrying out emergency measures; increasing the openness of the SAIs; raising public awareness of Covid-19; active publishing activities on Covid-19; direct participation of the SAIs in the fight against Covid-19; advanced training of SAIs employees.

5. At the international level, in the field of audit, the pandemic has given a new impetus to the diversification of its types within a single audit company. Currently, experiencing a boom: health audit; audit of the banking sector; audit of digital transformation measures; audit of agriculture; education audit; audit of overpricing of basic necessities and medical supplies; audit of the implementation of support for citizens affected by Covid-19; audit of funds and donations in the framework of pandemic prevention and control measures; audit of the expenditure of funds allocated for the fight against Covid-19, and; government spending on Covid-19.

6 . To solve the problem of economic control of the Covid-19 pandemic in the conditions of Ukrainian realities, I propose to use the experience of the Colombian SAIs, which has introduced a real-time monitoring center, which will carry out preventive and constant monitoring are made by the government and municipal bodies.

7. The problem of informing entrepreneurs about the measures taken by the government to combat the pandemic has been solved by the introduction of an online information platform by public authorities, however, it is advisable to make the same platform locally, at the city level, or at least to establish timely monitoring of local realities, because it is the local government that establishes special local regimes and monitors their implementation.

8. The issue of ensuring the continuity of private companies, we advise solving by extending the tax holidays, the temporary abolition of fines (for companies for minor offenses, if they do not relate to the fight against the epidemic), extending the moratorium on inspections. It will allow focusing 
more on adapting to the new environment, which will help private audit activities. Given the small numbers within the country and the synergies for other industries, we believe this is the right move.

9. The pandemic caused a systemic shock and complicated the work of SAD with customers. The issue of adaptation of auditing to current conditions we propose to solve by introducing the use of several tools: outsourcing; innovative management format; intensification of search of clients and formation of their trust; development of complex solutions for consumers of audit services in the areas of audit, and; pricing optimization.

10. An urgent issue now is the receipt by the heads of structural units of operational, relevant, unbiased information on the state of the company's resources to make management decisions and plan management strategy. Therefore, in the current conditions of the pandemic, and, in the future, given the turbulence of the environment, we recommend conducting a systematic audit as a preventive method of control that will respond quickly to fluctuations in the economic environment, taking into account social and political factors, which are uncontrolled by the enterprise.

\section{REFERENCES}

Audit Chamber of Ukraine. (2019). Information on the state of auditing in Ukraine in 2019. In https://www.apu.com.ua/2019/06/27/інформація-про-станаудиторської-дія-2/.

Audit Chamber of Ukraine. (2020). Information notice on the reduction of the amount of the contribution paid by the auditing entities in favor of the Audit Chamber of Ukraine. In https://www.apu.com.ua/2020/05/12/інформаційнеповідомлення-щодо-змен/.

Audit Chamber of Ukraine. (2020). Regarding the non-application of penalties for late publication of financial statements for 2019: Letter 01-01-21/200. In https://www.apu.com.ua/2020/03/17/звернення_апу_3_листом/.

Chamber of Auditors and Accountants of Ukraine. (May 14, 2020). The coronavirus pandemic significantly affected the audit. In https://pabu.com.ua/ua/mediacentr3/profesiini-novyny/1636-pandemiia-koronavirusu-znachno-vplynula-na-audyt.

Clarke, K., Walsh, K. \& Flanagan J. (2015). How prevalent are post-completion audits in australia. Accounting, Accountability \& Performance, 18(2), 51-78. In https://search.informit.org/documentSummary;dn=469182346697207;res=IEL BUS; type $=$ pdf.

Colmenares Páramo, D. (June 19, 2020). Auditorías digitales y tiempo real. El Financiero. In https://www.elfinanciero.com.mx/opinion/david-colmenaresparamo/auditorias-digitales-y-tiempo-real. 
Dolbneva, D.V. (2018). The current state and areas of improvement of auditing in the context of European integration of Ukraine and the application of international standards. Economy and state, 2, 72-76. In http://www.economy.in.ua/?op=1\&z=3985\&i=15.

DQS CFS. (2020). Safely Forward: Certification for Hygiene \& Infection Prevention. In https://dqs-cfs.com/portfolio/hygiene-infection-prevention-due-diligenceaudits-and-certification-for-the-disinfection-of-public-spaces/.

European Union. (2006). On statutory audits of annual accounts and consolidated accounts: Directive 2006/43/EU. In https://eur-lex.europa.eu/legalcontent/EN/TXT/?uri=celex\%3A32006L0043.

European Union. (2014). On specific requirements regarding statutory audit of publicinterest entities: Regulation 537/2014. In https://eur-lex.europa.eu/legalcontent/EN/TXT/?uri=CELEX\%3A32014R0537.

Ishaque, M. (2019). Managing Conflict of Interests in Professional Accounting Firms: A Research Synthesis. Journal of Business Ethics, 2. DOI https://doi.org/10.1007/s10551-019-04284-8.

Kashperska, A.I. (2018). Current state and prospects of audit activity development in Ukraine. Economy and society, 19, 1272-1280. DOI: https://doi.org/10.32782/2524-0072/2018-19-190.

KPMG. (2020). Colombia: Government and institution measures in response to COVID19. In https://home.kpmg/xx/en/home/insights/2020/04/colombia-governmentand-institution-measures-in-response-to-covid.html.

Ladda, R.L. (2014). Basic Concepts of Accounting. Solapur: Laxmi Book Publication.

Loeb, S. E. \& Shamoo, A. E. (1989). Data audit: Its place in auditing. Accountability in Research, 1(1), 23-32. DOI: 10.1080/08989628908573771.

Matthews, D. (2006). History of Auditing: The changing audit process from the 19th century till date. UK: Routledge.

MinFin. (2020). Gross domestic product. In https://index.minfin.com.ua/economy/gdp/2019/.

Moore, D., Tetlock, P.D., Tanlu, L. \& Bazerman, M.H. (2006). Conflicts of Interest and the Case of Auditor Independence: Moral Seduction and Strategic Issue Cycling. The Academy of Management Review, 31(1), 10-29. DOI: 10.5465/AMR.2006.19379621.

Mulyk, Y.I. (2020). Auditing in Ukraine: current status, reform and development. Agrosvit, 7, 37-47. DOI: 10.32702/2306-6792.2020.7.37.

Nakonechna, N.V. \& Melnyk, S.I. (2018). The role of internal audit in the system of economic security of the enterprise. Scientific bulletin, 2, 176-183. In https://www.lvduvs.edu.ua/documents_pdf/visnyky/nvse/nvse_02_2018/20.pdf.

Petrytska, O.S. (2019). Organization of internal audit at enterprises. Priazovsky Economic Bulletin, 5(16), 356-359. DOI: https://doi.org/10.32840/2522-4263/2019-5-61. 
Popov, A. (March, 3, 2020). Audit trends-2020: IAASB, tax reform, digitalization. Visnyk. In http://www.visnuk.com.ua/uk/news/100016751-trendi-auditu-2020iaasb-podatkova-reforma-didzhitalizatsiya

Prokhorova, L.I. \& Yukhimenko, E.S. (2019). Analysis of the current state and problems of reforming and development of auditing in Ukraine on the basis of international experience. A young scholar, 6(2), 205-210. In http://nbuv.gov.ua/UJRN/molv_2019_6\%282\%29_14.

Russian Federation. The Accounts Chamber. (2020). Supreme Audit Institutions Response to the Covid-19 2020 Pandemic. In https://ach.gov.ru/upload/pdf/Covid-19SIA.pdf.

Shevchenko, I.O. \& Lipnytska, M.V. (2019). The essence and development of audit in European integration conditions. Scientific and practical journal "Black Sea Economic Studies", 38. In http://repository.hneu.edu.ua/handle/123456789/21802.

Shulga, S.V. (2019). Theoretical aspects of the classification of audit services in terms of legislative innovations. Economy and state, 7, 63-68. DOI: 10.32702/23066806.2019.7.63.

Sonin, A. (April 13, 2020). Pandemic is an internal audit challenge. GAAP.RU. In https://gaap.ru/articles/Pandemiya_vyzov_dlya_vnutrennego_audita/.

Stangoe, D. \& Milan, Z. (2020). Auditing in the Age of COVID-19: Waste of Resources or an Opportunity We Cannot Afford to Waste? Clinical Audit, 12, 11-12. DOI https://doi.org/10.2147/CA.S275214.

Ukraine. (1984). Code of Ukraine on Administrative Offenses. In https://zakon.rada.gov.ua/laws/show/80731-10\#Text.

Ukraine. (1999). On accounting and financial reporting in Ukraine: Law 996-XIV. In https://zakon.rada.gov.ua/laws/show/996-14\#Text.

Ukraine. (2003). Commercial Code. In https://zakon.rada.gov.ua/laws/show/436-15.

Ukraine. (2003). On Environmental Audit: Law 1862-IV. In https://zakon.rada.gov.ua/laws/show/1862-15\#Text.

Ukraine. (2003). On the audit of financial statements and auditing activities: Law 2258VIII. In https://zakon.rada.gov.ua/laws/show/ 2258-19.

Zhukova, T.A., Ganus, I.S. \& Plikus, I.J. (2019). Analysis of the audit services market in Ukraine. Bulletin of Sumy State University. Economics series, 2, 63-69. DOI: 10.21272/ 1817-9215.2019.2-8. 